\title{
Indigenous Curative Plants Used in the Treatment of Piles from Akinyele Local Government Area, Ibadan, Oyo State, Nigeria
}

\author{
O. C. Ariyo ${ }^{1^{*}}$, M. B. Usman ${ }^{2}$, U. U. Emeghara ${ }^{2}$, M. M. Olorukooba ${ }^{2}$, O. K. Fadele ${ }^{2}$, \\ C. A. Danbaki ${ }^{2}$, O. E. Olagunju ${ }^{2}$, R. Suleiman ${ }^{2}$ and M. O. Ariyo ${ }^{2}$ \\ ${ }^{1}$ Department of Vocational and Technical Studies, Federal College of Forestry Mechanization, \\ Forestry Research Institute of Nigeria, Nigeria. \\ ${ }^{2}$ Federal College of Forestry Mechanization, Forestry Research Institute of Nigeria, Nigeria.
}

\section{Authors' contributions}

This work was carried out in collaboration among all authors. Author OCA designed the study, performed the statistical analysis, wrote the protocol and wrote the first draft of the manuscript. Authors MBU, UUE, MMO and OKF managed the analyses of the study. Authors CAD, OEO, RS and MOA managed the literature searches. All authors read and approved the final manuscript.

Article Information

DOI: 10.9734/ARRB/2020/v35i630238

Editor(s):

(1) Prof. Tunira Bhadauria, Kanpur University, India.

Reviewers:

(1) Abhijeet Vishnu Puri, University of Mumbai, India. (2) Bárbara Arias Toledo, Universidad Nacional de Córdoba, Argentina. (3) Ronald Fernando Quintana Arias, Universidad Distrital Francisco José De Caldas, Colombia. Complete Peer review History: http://www.sdiarticle4.com/review-history/57648

Original Research Article

Received 24 April 2020

Accepted 29 June 2020

Published 13 July 2020

\section{ABSTRACT}

Piles are inflammation of blood vessels which are generally found close to the anal canal. Piles are produce when the anal cushions are disrupted during defecation. The importance of the knowledge of indigenous remedial medicinal plants in curing piles has not been fully acknowledged from rural, folkloric background of Nigerian society. The present study attempt to document indigenous knowledge and curative plants used in the treatment of pile in Akinyele Local Government Area, Ibadan, Oyo State, Nigeria. Eight villages were purposively selected and respondents stratified into four strata in each of the villages. Semi - structured and open-ended questionnaires was used to obtained information from local herb sellers, hunters, herbalists and aged. The data collected were analysed using descriptive statistics. The result showed that a total number of 25 plant species 
belonging to 19 families, were recorded and enumerated along with their botanical, family and local names. Fabaceae sub family of Caesalpinioidea, Mimisoideae and Palpilinoideae contributed the highest number of 4 plant species used in the treatment of pile. The plant part used includes leave, bark, seeds roots, vines, rhizome, bulbs, cobs, and bunch with high frequency of leaves been used. The method of preparation of recipe, mode of administration, dosage and shelf life of the recipe used for the treatment of piles were discussed. Many of the medicinal plants used in the treatment of piles are rare and found in the wild, the study concludes that there is need for domestication and sustainable conservative efforts from the researchers, government and community to safeguard the loss of these important medicinal plants. There is need for further studies on the phytochemical and pharmacological properties of these plants.

Keywords: Piles; medicinal plants; indigenous knowledge; treatment; families.

\section{INTRODUCTION}

Herbal plants have been shown to have genuine utility and about $80 \%$ of the rural population depends on them as primary health care [1]. Plants have been used as sources of remedies for the treatment of many diseases since ancient times and people of all continents especially Africa have this old tradition [2]. A vast knowledge of how to use the plants against different illnesses may be expected to have accumulated in areas where the use of plants is still of great importance [3].

A large proportion of indigenous populations rely on medicinal plants to meet their health care needs in many developing nations. According to [4], botanically derived medicinal plants have played a major role in human history and people have used plants as medicine since the beginning of civilization, as they were believed to have healing powers [5]. The use of plants in the tropical and subtropical regions is diversified and most of the uses are for medicine, source of food, clothing and shelter.

Piles are also known as haemorrhoids, are normal part of human anatomy which is present in every age group from the new born to the elderly, though with notable differences in size. It is caused by increased pressure in the veins of the rectum or anus resulting from straining when trying to have a bowel movement or any activity causing straining, such as heavy lifting. As pressure increases, blood pools in the veins, increases and this causes them to swell thus stretching the surrounding tissue [6]. Haemorrhoids can be inside and/or outside the anus and they are not dangerous as suggested by [7]. Internal Haemorrhoids may be located near the beginning of the anal canal or close to the anal opening. When it protrudes outside the anal opening, they are referred to as prolapsed haemorrhoids.

Duke [8] pointed out clearly that about $25 \%$ of all Africans has had haemorrhoids at age 50 and that $50 \%$ to $85 \%$ of the World population could have been affected by haemorrhoids at some time in their life. Pile affect both sexes but the impact on males appear to be more of concern because of its effect on their sexual performance [9]. This disease appears to be genetically inherited as some children suffer this ailment. Humans are prone to Haemorrhoids because the erect posture of man puts a lot of pressure on the veins in the anal region [10]. According to [11], overeating and presence of unassimilated bulk foods are also known to cause haemorrhoids as well as intoxicating liquors, artificial flavouring or spices, white bread, cakes, all other white flour products, fried foods, sugar and all soft drinks.

The indigenous flora continues to play a key role in the livelihood of people in developing countries today. [12] opined that the Nigeria flora has already and will continue to make a great contribution to the health care of Nigerians. The indigenous medicinal plants form an important component of the natural wealth of Nigeria. Many indigenous plants have been used by common man since time immemorial for curing various ailments and thus lessening human suffering without the actual knowledge of the active ingredient which cause relief [13]. The potentialities of some of these plants have been established. Herbalists have used various plant parts which include stems, leaves, roots, shoot of plant or whole plant to prepare extracts, decoction, concoction, mixtures, creams, soaps, infusions, pastes, macerations, syrup and powders for ingredients of plant(s) subjected to partial combustion used in various manipulation 
according to herbalists prescriptions to cure several ailments.

The medicinal uses of plants are rapidly declining among the present generation of local people as a consequence of modernization and civilization [14]. Moreover, the younger generation is showing little interest in learning this valuable science of healing [2]. Also, usage of medicinal plants to cure diseases has also been much influenced by religious practices $[15,16]$. All over the world, several ethnobotanical studies focusing on medicinal plants have been documented [17,18,19,20,14,21,22]. However, in Nigeria, information available on ethnobotanical studies of plants used especially in the study, in the treatment of pile is scarce. Hence, the present study documents medicinal plants for treatment of piles used by local communities of Akinyele Local Government Area, Ibadan, Oyo State, Nigeria.

\section{MATERIALS AND METHODS}

\subsection{Study Area}

The research was carried out at Akinyele Local Government Area of Ibadan Oyo State, Nigeria. It is one of the eleven local governments that make up Ibadan metropolis. Its headquarters is located at Moniya. It has latitude of $7^{\circ} 28^{\prime}$ and $7^{\circ}$ $31^{\circ}$ and longitude $3^{\circ} 53^{\circ}$ and $3^{\circ} 57^{\circ}$ [23]. The Local Government Area is five hundred and seventy five square kilometres $\left(575 \mathrm{~km}^{2}\right)$ with twelve polling wards and a projected population of 297,600 as at 2016 from the 2006 national population census [24]. It is located in the rain forest zone and grassland of South Western Nigeria. The area has a tropical climate, which is characterised by two distinct seasons; the raining season and the dry season. The raining season begins in April and last till October while the dry season commences in November and last till March. The average annual rainfall is about 1200 $\mathrm{mm}$ and ecological zone type is forest savanna. Akinyele Local Government is highly heterogeneous and metropolitan in nature especially areas like Ojoo, Orogun, Sasa, Moniya and Akinyele where Nigerians from different tribes and foreign nationals reside. The major occupations of the people residing in the area are farming, carpentry, trading, marketing, food processing as well as carving work. Crop such as oil palm, cassava, maize, yam, pepper, cucumber, water melon, tomatoes, plantain and okra are mostly grown in the area $[25,23]$.

\subsection{Method of Data Collection}

Primary data was used for this study. The instrument for data collection was interview schedule which consisted of a series of semistructured and open-ended questionnaires administered to local herb sellers, hunters, herbalists and aged by personal interview within the Local Government. The administration of questionnaires by personal interview method was done for eight months between April to December 2017. The questionnaires administration and interviews were done in the native language (Yoruba language) of the respondents. During the interview, the information regarding medicinal plants used in the treatment of pile, local names of the plant, plant parts used and the form in which it is used, methods of preparation and mode of administration, doses and shelf life of the herbal recipes were collected from the respondents and documented. The local names of plants mentioned were interpreted to their respective biological names using the publication by [26]. The information gathered from the respondents was sorted and harmonized, only information confirmed by three or more respondents were reported.

\subsection{Sampling Techniques and Sample Size}

Multi stage sampling techniques was used for this study. The first stage was the purposive selection of eight villages in the local governments due to the relics of forest and presence of local herb sellers, hunters, herbalists and aged people in those villages. The villages are ljaye, Onidundu, Otunagbakin, Moniya, Idiose, Apapa, Aroro and Olanla. The second stage involved the stratification of respondents into four groups in each of the villages: Local herb sellers, hunters, herbalists and aged. The third stage was the random selection of 5 respondents in each stratum making total number of 160 respondents that was used for the study.

\subsection{Data Analysis}

The data collected were analysed with descriptive statistics such as tables, frequency counts and percentages.

\section{RESULTS AND DISCUSSION}

The plant used in the treatment of piles in the study area is presented on Table 1. A total 
number of 25 plants species belong to 19 families were recorded in the treatment of pile in the study area (Tables $1 \& 5$ ). [13] found a total number of 144 plant species belonging to 58 different families used in the treatment of haemorrhoids in South-Western Nigeria, 20 of which were also documented in this study while 5 plant species such as Ocimum canum, Imperata cylindrical, Angylocalyx oligophyllus, Lophira lanceolata and Triplochiton scleroxylon are new and serve as additional information to the plants used in the treatment of pile. [27] found 12 plant species belonging to 11 families in the treatment of piles of Betbari area in Sivasagar District of Assam, India while [28] documented 29 plant species belonging to 27 genera distributed over 19 families (15 dicotyledons, 3 monocotyledons and 1 gymnosperm) used in the treatment of piles.

\subsection{Plant Growth Form Analysis}

The plant growth form analysis of the 25 medicinal plants recorded and presented on Table 2 showed that 9 species are trees $(36 \%), 6$ species are shrubs (24\%), 5 species are herbs $(20 \%)$, and 5 species are climbers $(20 \%)$. This finding shows that the most represented life forms of medicinal plants used in the treatment of piles in the study area were trees, shrubs, herbs and climbers. [27] reported that $50 \%$ of the plants found in the treatment of piles are herbaceous, $25 \%$ trees, $16.6 \%$ shrubby and $8.3 \%$ are climbers. The growth form analysis of medicinal plants according to [29] revealed that shrubs constitute the highest proportion being represented by 34 species $(48.6 \%)$, herbs represented by 17 species $(24.3 \%)$, trees represented by 13 species (18.6\%), and climbers represented by 5 species $(7.1 \%)$, while there was one species $(1.4 \%)$ of epiphyte.

\subsection{Habitat and Abundance of Medicinal Plants}

Part of Table 1 also showed the habitat, abundance and cultivation of medicinal plants used in the treatment of pile in the study area. According to the respondents, 14 plant species used in the treatment of piles are found in the wild (forest) while only 7 species are cultivated. Various studies conducted in Ethiopia reported that most of medicinal plants are being harvested from non-cultivated areas. For instance, the study conducted by [30] indicated that the highest number $(90.43 \%)$ of medicinal plants was collected from wild in Mana Angetu District. Similarly, [31] and [32] reported that about 54\% and $49 \%$ of medicinal plants were harvested from wild in Tehuledere and Halaba districts, respectively. This observation is a good indication of the fact that the local people have not yet started cultivating most of the plant species they are using as remedies. [33] stated that relatively few medicinal and aromatic plant species are cultivated. The greater majority is still provided by collection from the wild [34,35]. In terms of the abundance of the plants, 13 species are common and can easily be found from the surroundings or sourced from herb sellers, 12 of the plants are rare and cannot easily be sourced. This raises concern about the need for both short and long term intervention strategies to save the species from extinction. There is an urgent need for an official policy on the development and upgrading of local medicinal plants, which complement orthodox therapy in Nigeria. The habitat of the plants showed that 18 species are found in the forest, 10 species in the savannas and 10 plant species are found on farmland; however it should be noted that the habitat of some species overlaps. 20 species are indigenous or native plants while only 5 species are exotic or introduced. This agrees with the findings of [36] which stated that the majority of plants utilized by the respondents are native species collected from forest habitat. This showed that the wild habitats are important for local communities in terms of basic needs. [37] also pointed to the importance of wild habitats for people's livelihood in a rural community of Mexico and found a greater diversity of plant uses in wild habitats than in managed environments.

\subsection{Floristic Analysis}

Tables 1 and 3 showed the plant parts and form in which they are used by the respondents in the treatment of piles which includes fresh or dried leave, bark, seeds roots, vines, rhizome, bulbs, cobs, and bunch. This agreed with [38] which stated that plant parts are being used for the healing of disease from the prehistoric times. Leaves of 7 plant species (28\%), bark of 6 plant species $(24 \%)$, seeds of 4 plant species $(16 \%)$, root of 2 plant species $(8 \%)$, vines of 2 plant species $(8 \%)$, rhizome, bulb, cob and bunch of 1 plant species each $(4 \%)$ are the plant parts commonly used in the preparation of herbal medicine (recipe) for the treatment of piles in the study area. This showed that leaves form the major plant part used. This agrees with the findings of $[32,39,40,41,42]$ which indicated that traditional medicinal preparations mainly involve 
the use of leaves. As leaves of medicinal plant species were also reported to be harvested for most remedy preparations next to roots, collection of leaves could be promoted as a more sustainable method since in most cases at least many leaves are left over on the parent plant [43]. However, plant harvest involving roots, rhizomes, bulb, bark, and stem has a serious effect on the survival of the mother plant in its habitat [44]. Apart from plant parts, insect such as Centipede (Scutigera coleoptrata) and other 4 non plant materials like water, hot drinks/ Local gin/ Schnapps, "Kafura" and Waji's cloth were also used in the preparation of recipe (Tables 4 and 6). [9] found only 1 animal- lizard's eggs and 9 other ingredients such as native soap, gin/local gin/schnapps, black thread, fermented corn extract, salt, potash, waji's cloth, white thread and sugar were described as being used in the preparation of traditional remedies for the treatment of piles and diabetes mellitus in Oyo State, Nigeria.

\subsection{Comparative Analysis of the Families}

The plant species distribution used in the treatment of pile according to the families is presented on Table 5. A total number of 19 families were recorded for all the 25 plant species used in the treatment of piles in the study area. Fabaceae sub family of caesalpinioideae, mimisoideae and palpilinoideae contributed the highest number of 4 plant species which is equivalent to $16 \%$. This was followed by Combretaceae, Euphorbiaceae, Meliaceae, Poaceae and Zingiberaceae with 2 plant species each ( $8 \%$ each). The families such as Apocynaceae, Arecaceae, Aristolochiaceae, Asclepiadaceae, Asclepiadaceae, Asteraceae, Cucurbitaceae, Fabaceae- papilionoideae, Fabaceae-mimosoideae, Lamiaceae, Liliaceae, Ochnaceae, Piperaceae and Sterculiaceae are represented by only one species ( $4 \%$ each). The families with single specie call for special attention in the area of conservation. Similar observation was made by [13]. According to the report of [28], the families Zingiberaceae, Lamiaceae and Mimosaceae with 4 species each have contributed maximum number of species in the treatment of piles which is followed by Liliaceae with 2 species. The remaining 15 families have only 1 species each used in piles treatment.

\subsection{Use Analysis}

The method of preparation of recipes, mode of administration, dosage and shelf life of the recipe used for the treatment of piles is presented on Table 7. Thirteen (13) different herbal medicines (recipes) were documented in the study area. It was observed in table 3 and 7 that respondents used parts of single plant or combination of more than two plants and water, palm kernel oil and hot drinks as a medium of preparation of the recipe used for the treatment of piles, similar report was made by [27]. According to the respondents, the potency of using a mixture of different plant or plant parts increased compared to using a single plant to cure a disease. This agrees with the findings of [29]. The emphasis of the synergism of more than one medicinal plant was emphasized by the informants [45].

The method of preparation of recipe varied, which include decoction, soaking in water or hot drink, squeezing, boiling in water, burning and grinding into powder. According to [9], the method of preparation of herbal medicine for the treatment of diabetes mellitus and piles varied widely, which include infusion, decoction, maceration, squeezing, burning, boiling (in water), soaking, grinding/pounding, drying and pulverization into powder and many other variant methods. The mode of administration of recipe in the study was mainly by drinking (oral administration) and topical application. This is similar to a study conducted in Bolivia which shows that, the most frequently used route of administration of herbal medicine is oral ingestion [46]. This was in line with the finding of [9] which stated that oral administration was the only mode of administration of the herbal treatment for diabetes mellitus while topical application and oral administration were employed for the treatment of piles in the study areas in Oyo State. Also, [47] stated that drinking was found to be the most preferred mode of administration of herbal medicine while rubbing and bathing were less frequently employed in the treatment of viral diseases infection. The dosage of the herbal medicine used in the treatment of pile varied from drinking full or half stainless cup or glass cup of the recipe once or twice daily, one "gas" in the morning daily, and two spoonfuls twice daily however, there is no standardization and precision of dosage. This agree with the findings of [48] which stated that lack of standardization and precision on dosage and quality control is seen as one of the main disadvantages of traditional medicine. The lack of precise dosage is one of the drawbacks of traditional medicinal plants [49]. 
Table 1. Plants used in the treatment of pile in the study area

\begin{tabular}{|c|c|c|c|c|c|c|c|}
\hline $\mathbf{S} / \mathbf{n}$ & Botanical names & Family name & Form & Common names & Local name & $\begin{array}{l}\text { Plant part and } \\
\text { form used }\end{array}$ & $\begin{array}{l}\text { Habitat, Cultivation, } \\
\text { Abundance (Rare/ common), } \\
\text { Native/ Introduced }\end{array}$ \\
\hline 1 & Momordica charantia Linn. & Cucurbitaceae & Climber & $\begin{array}{l}\text { African cucumber, } \\
\text { Bitter cucumber }\end{array}$ & Ejinrin-were & Fresh leaves & $\begin{array}{l}\text { Forest/ farmland, common, wild, } \\
\text { native }\end{array}$ \\
\hline 2 & Jatropha gossypifolia Linn & Euphorbiaceae & Shrub & $\begin{array}{l}\text { Bellyache bush, } \\
\text { Red physic nut }\end{array}$ & $\begin{array}{l}\text { Lapalapa } \\
\text { pupa }\end{array}$ & Fresh leaves & $\begin{array}{l}\text { Savanna, wild. } \\
\text { Common, exotic }\end{array}$ \\
\hline 3 & Ocimum canum Sims & Lamiaceae & Shrub & Saint leaf & Efinrin & Fresh leaves & $\begin{array}{l}\text { Forest/ savanna, wild, common, } \\
\text { cultivated, native }\end{array}$ \\
\hline 4 & Khaya grandifoliola C. DC. & Meliaceae & Tree & African mahogany & Oganwo & $\begin{array}{l}\text { Fresh or dried } \\
\text { bark }\end{array}$ & Forest, rare, wild, native \\
\hline 5 & $\begin{array}{l}\text { Pteleopsis suberosa Engl. } \\
\text { \& Diels }\end{array}$ & Arecaceae & Tree & Rattan palms & Okuku & $\begin{array}{l}\text { Fresh or dried } \\
\text { bark }\end{array}$ & Forest, rare wild, native \\
\hline 6 & Bridelia micrantha (Hochst.) Baill. & Euphorbiaceae & Shrub & Bridelia, Assas & Ira & $\begin{array}{l}\text { Fresh or dried } \\
\text { bark }\end{array}$ & Forest, rare wild, native \\
\hline 7 & $\begin{array}{l}\text { Acacia nilotica (Linn.) Wild ex. } \\
\text { Del. }\end{array}$ & Fabaceae-Mimo & Shrub & Bonni & Booni & Dried seed & Forest, common, wild, exotic \\
\hline 8 & Allium sativum Linn. & Liliaceae & Herb & Garlic & Alubosa ayu & Dried bulb & $\begin{array}{l}\text { Farmland/savanna, common, } \\
\text { cultivated, native }\end{array}$ \\
\hline 9 & Zingiber officinale Roscoe & Zingiberaceae & Herb & Ginger & Ata ile & $\begin{array}{l}\text { Fresh or dried } \\
\text { ginger (rhizome) }\end{array}$ & $\begin{array}{l}\text { Farmland/ savanna, cultivated, } \\
\text { common, exotic }\end{array}$ \\
\hline 10 & Zea mays Linn. & Poaceae & Herb & Maize & Suku-agbado & $\begin{array}{l}\text { Dried cob from } \\
\text { dumping ground }\end{array}$ & $\begin{array}{l}\text { Farmland/ savanna, cultivated, } \\
\text { common, exotic }\end{array}$ \\
\hline 11 & Senna alata Linn. & Fabaceae- Caes. & Shrub & $\begin{array}{l}\text { Emperor's } \\
\text { candlesticks }\end{array}$ & $\begin{array}{l}\text { Asuwon- } \\
\text { oyinbo }\end{array}$ & $\begin{array}{l}\text { Fresh tender } \\
\text { leaves }\end{array}$ & $\begin{array}{l}\text { Forest, savanna, farmland, rare, } \\
\text { wild, native }\end{array}$ \\
\hline 12 & Imperata cylindrica (L.) Raeusch. & Poaceae & Herb & Spear grass & $\begin{array}{l}\text { Ekan, Ireke- } \\
\text { obo }\end{array}$ & Dried root & $\begin{array}{l}\text { Both savanna \& forest transition, } \\
\text { farmland, wild, common, native }\end{array}$ \\
\hline 13 & $\begin{array}{l}\text { Angylocalyx oligophyllus (Baker) } \\
\text { Baker f. }\end{array}$ & Fabaceae- pap. & Climber & & Oko-aja & Fresh leaves & Forest, wild, rare, native \\
\hline 14 & Aristolochia repens Mill & Aristolochiaceae & Tree & Dutchman's pipe & Akogun & $\begin{array}{l}\text { Fresh or dried } \\
\text { bark }\end{array}$ & Forest, wild, rare, native \\
\hline 15 & $\begin{array}{l}\text { Picralima nitida (Stapf) T. Durand \& } \\
\text { H. Durand }\end{array}$ & Apocynaceae & Tree & $\begin{array}{l}\text { Akuamma plant, } \\
\text { Picralima }\end{array}$ & Abere & Dry seed & Forest, wild, rare, native \\
\hline 16 & $\begin{array}{l}\text { Terminalia glaucescens Planch. ex } \\
\text { Benth. }\end{array}$ & Combretaceae & Tree & & Idi-apata & $\begin{array}{l}\text { Fresh or dried } \\
\text { bark }\end{array}$ & Forest, wild, rare, native \\
\hline
\end{tabular}


Ariyo et al.; ARRB, 35(6): 78-89, 2020; Article no.ARRB. 57648

\begin{tabular}{|c|c|c|c|c|c|c|c|}
\hline 17 & $\begin{array}{l}\text { Anogeissus leiocarpus (DC.) Guill. \& } \\
\text { Perr. }\end{array}$ & Combretaceae & Tree & $\begin{array}{l}\text { African birch, or } \\
\text { chewstick tree, } \\
\text { Axlewood }\end{array}$ & Ayin & $\begin{array}{l}\text { Fresh or dried } \\
\text { bark }\end{array}$ & Forest, wild, rare, native \\
\hline 18 & Cassia fistula L. & Fabaceae- Caes. & Tree & Golden tree & Aidantooro & $\begin{array}{l}\text { Fresh or dry } \\
\text { seed }\end{array}$ & Savanna, wild, rare, native \\
\hline 19 & Gongronema latifolium Benth & Asclepiadaceae & Climber & $\begin{array}{l}\text { Swallow apple, } \\
\text { Utazi }\end{array}$ & Madunmoro & $\begin{array}{l}\text { Fresh or dried } \\
\text { vine }\end{array}$ & $\begin{array}{l}\text { Forest, abandoned farmland, } \\
\text { wild, rare, native }\end{array}$ \\
\hline 20 & Lophira lanceolata Tiegh. ex Keay & Ochnaceae & Climber & $\begin{array}{l}\text { (Dwarf red } \\
\text { ironwood }\end{array}$ & Paran pupa & $\begin{array}{l}\text { Fresh or dried } \\
\text { vine }\end{array}$ & $\begin{array}{l}\text { Forest, abandoned farmland, } \\
\text { wild, rare, native }\end{array}$ \\
\hline 21 & $\begin{array}{l}\text { Aframomum meleguecta (Roscoe) } \\
\text { K. Schum. }\end{array}$ & Zingiberaceae & Herb & Alligator pepper & Atare & One bunch & $\begin{array}{l}\text { Forest/ farmland, cultivated, } \\
\text { common, native }\end{array}$ \\
\hline 22 & Azadirachta indica A. Juss. & Meliaceae & Tree & Neem tree & Dogoyaro & $\begin{array}{l}\text { Fresh or dried } \\
\text { roots }\end{array}$ & $\begin{array}{l}\text { Savanna, farmland, common, } \\
\text { exotic }\end{array}$ \\
\hline 23 & Piper guineense Schum. \& Thonn. & Piperaceae & Climber & $\begin{array}{l}\text { African black } \\
\text { pepper or bush } \\
\text { pepper }\end{array}$ & lyere & $\begin{array}{l}\text { Fresh or dry } \\
\text { seed }\end{array}$ & $\begin{array}{l}\text { Forest/ farmland, cultivated/ wild, } \\
\text { common, native }\end{array}$ \\
\hline 24 & Vernonia amygdalina Delile & Asteraceae & Shrub & Bitter leaf & Ewuro & Fresh leaves & $\begin{array}{l}\text { Both forest and savanna, } \\
\text { cultivated, common, indigenous }\end{array}$ \\
\hline 25 & Triplochiton scleroxylon K. Schum & Sterculiaceae & Tree & Obeche & Arere & $\begin{array}{l}\text { Young growing } \\
\text { fresh leaves }\end{array}$ & $\begin{array}{l}\text { Forest, wild, common, } \\
\text { indigenous }\end{array}$ \\
\hline
\end{tabular}

Source: Field survey data, 2017 
Table 2. Plant growth form distribution of medicinal plants

\begin{tabular}{llll}
\hline S/N & Plant form & Frequency & Percentage \\
\hline 1 & Tree & 9 & 36 \\
2 & Shrub & 6 & 24 \\
3 & Herb & 5 & 20 \\
4 & Climber & 5 & 20 \\
\hline Total & & $\mathbf{2 5}$ & $\mathbf{1 0 0}$ \\
\hline
\end{tabular}

Table 3. Plant parts used for treating pile

\begin{tabular}{lll}
\hline Plant parts used & Frequency & \% Occurrence \\
\hline Leaves & 7 & 28 \\
Bark & 6 & 24 \\
Seeds & 4 & 16 \\
Roots & 2 & 8 \\
Vines & 2 & 8 \\
Rhizome & 1 & 4 \\
Bulb & 1 & 4 \\
Cob & 1 & 4 \\
Bunch & 1 & 4 \\
\hline Total & $\mathbf{2 5}$ & $\mathbf{1 0 0}$ \\
\hline \multicolumn{2}{l}{}
\end{tabular}

Table 4. Insect used for herbal medicine in the treatment of pile

\begin{tabular}{lllllll}
\hline S/n & $\begin{array}{l}\text { Botanical } \\
\text { names }\end{array}$ & $\begin{array}{l}\text { Family } \\
\text { name }\end{array}$ & $\begin{array}{l}\text { Common } \\
\text { names }\end{array}$ & $\begin{array}{l}\text { Local } \\
\text { name }\end{array}$ & Part used & $\begin{array}{l}\text { Habitat, Abundance } \\
\text { (Rare/ common) }\end{array}$ \\
\hline 1 & $\begin{array}{l}\text { Scutigera } \\
\text { coleoptrata }\end{array}$ & Chilopoda & Centipede & Okuun & $\begin{array}{l}\text { Whole } \\
\text { centipede }\end{array}$ & $\begin{array}{l}\text { Forest/ farmland, } \\
\text { common, }\end{array}$ \\
\hline & & Source: Field survey data, 2017 &
\end{tabular}

Table 5. Species distribution according to families

\begin{tabular}{llll}
\hline S/N & Families & Number of species & Percentage \\
\hline 1 & Apocynaceae & 1 & 4 \\
2 & Arecaceae & 1 & 4 \\
3 & Aristolochiaceae & 1 & 4 \\
4 & Asclepiadaceae & 1 & 4 \\
5 & Asteraceae & 1 & 4 \\
6 & Combretaceae & 2 & 8 \\
7 & Cucurbitaceae & 1 & 4 \\
8 & Euphorbiaceae & 2 & 8 \\
9 & Fabaceae- Caes. & 2 & 8 \\
10 & Fabaceae- pap. & 1 & 4 \\
11 & Fabaceae-Mimo & 1 & 4 \\
12 & Lamiaceae & 1 & 4 \\
13 & Liliaceae & 1 & 4 \\
14 & Meliaceae & 2 & 8 \\
15 & Ochnaceae & 1 & 4 \\
16 & Piperaceae & 1 & 4 \\
17 & Poaceae & 2 & 8 \\
18 & Sterculiaceae & 1 & 4 \\
19 & Zingiberaceae & 2 & 8 \\
& Total & 25 & 100 \\
\hline
\end{tabular}


Table 6. List of non-plant materials used in preparation of herbal recipe for pile treatment

\begin{tabular}{ll}
\hline $\mathbf{S} / \mathbf{N}$ & Non plant material \\
\hline 1 & Water \\
2 & Hot drinks/ Local gin/ Schnapps \\
3 & Kafura \\
4 & Waji's cloth \\
\hline & Source: Field survey data, 2017
\end{tabular}

Table 7. Enumeration of the recipes for the treatment of pile

\begin{tabular}{|c|c|c|c|}
\hline $\mathbf{S} / \mathbf{n}$ & Method of preparation of recipes & $\begin{array}{l}\text { Mode of administration } \\
\text { and dosage }\end{array}$ & Shelf life \\
\hline 1 & $\begin{array}{l}\text { Fresh leaves of Momordica charantia, Jatropha gossypifolia } \\
\text { and Ocimum canum are squeeze together with water and } \\
\text { filtered. }\end{array}$ & $\begin{array}{l}\text { Drink half stainless cup of } \\
\text { the filtrate two times daily. }\end{array}$ & A day \\
\hline 2 & $\begin{array}{l}\text { Cut the bark of Khaya grandifoliola, Ancistrophyllum } \\
\text { secundiflorum, Bridelia micrantha into pieces and put inside } \\
\text { plastic bottles, add clean water and kafura to it and covered. }\end{array}$ & $\begin{array}{l}\text { Drink one gas everyday in } \\
\text { the morning. }\end{array}$ & $\begin{array}{l}\text { Until it } \\
\text { finishes }\end{array}$ \\
\hline 3 & $\begin{array}{l}\text { Cut all the bark of Khaya grandifoliola, Pteleopsis suberosa, } \\
\text { Bridelia micrantha, Acacia nilotica, Picralima nitida, Allium } \\
\text { sativum, Aristolochia repens, Zingiber officinale, into pieces } \\
\text { and put inside plastic bottles, add clean water and kafura to } \\
\text { it and covered. }\end{array}$ & $\begin{array}{l}\text { Drink one gas in the } \\
\text { morning every day. }\end{array}$ & $\begin{array}{l}\text { When it } \\
\text { becomes } \\
\text { tasteless }\end{array}$ \\
\hline 4 & $\begin{array}{l}\text { Boil the tender leaves of Senna alata (asunwon-oyinbo) with } \\
\text { small quantity of water. Use the water to prepare amala that } \\
\text { you can finish at once. }\end{array}$ & $\begin{array}{l}\text { Eat the amala at once. } \\
\text { Repeat the process three } \\
\text { times every other day }\end{array}$ & A day \\
\hline 5 & $\begin{array}{l}\text { Collect small quantity of the root of Imperata cylindrica, dry it } \\
\text { and grind it to fine particles with the seed of Piper guineense } \\
\text { (lyere). Put it in palm kernel oil (adi) }\end{array}$ & $\begin{array}{l}\text { Take } 2 \text { spoonfuls twice } \\
\text { daily. }\end{array}$ & $\begin{array}{l}\text { Three } \\
\text { months }\end{array}$ \\
\hline 6 & $\begin{array}{l}\text { Bark of the Cassia fistula with Aristolochia ringens and } \\
\text { "Kafura" are soaked in a bottle containing water for at least } 3 \\
\text { hours. }\end{array}$ & $\begin{array}{l}\text { Drink half of stainless cup } \\
\text { a day. }\end{array}$ & $\begin{array}{l}\text { When it } \\
\text { becomes } \\
\text { tasteless }\end{array}$ \\
\hline 7 & Squeeze the leaves of Angylocalyx oligophyllus with water. & $\begin{array}{l}\text { Drink half stainless cup } \\
\text { daily. Use only once a } \\
\text { day. }\end{array}$ & A day \\
\hline 8 & $\begin{array}{l}\text { Collect plenty life centipede like } 10 \text { and put it inside a } \\
\text { covered container. It will dry and die inside the container or } \\
\text { dry the centipede inside the sun. Grind the dried centipede } \\
\text { into powder and divide the powder into two. Put one half } \\
\text { inside Waji cloth (the cloth can be got from herb seller } \\
\text { (alagbo). }\end{array}$ & $\begin{array}{l}\text { Sprinkle the other half on } \\
\text { the sheet (igbe) of the } \\
\text { person having chronic } \\
\text { pile. Use the half inside } \\
\text { waji cloth to push the } \\
\text { anus that came out inside. } \\
\text { Repeat the process every } \\
\text { other day three times. }\end{array}$ & \\
\hline 9 & $\begin{array}{l}\text { One dry maize cob from dumping site (Ori atan). The dry cob } \\
\text { of maize is use to clean the anus of the person that does not } \\
\text { have pile. The maize cob is burnt with one bunch of alligator } \\
\text { pepper. The person that uses the maize cob to clean the } \\
\text { anus must not use water to clean the bottom after going to } \\
\text { toilet that day. }\end{array}$ & $\begin{array}{l}\text { The person with pile will } \\
\text { use small quantity of the } \\
\text { powder to drink pap }\end{array}$ & $\begin{array}{l}\text { When the } \\
\text { powder } \\
\text { finishes }\end{array}$ \\
\hline 10 & $\begin{array}{l}\text { Fresh or dried bark of Aristolochia ringens, Khaya } \\
\text { grandifoliola, Terminalia glaucescens, Anogeissus leiocarpus } \\
\text { and fresh or dried vine of Gongronema latifolium, Lophira } \\
\text { lanceolata and dried seed of Picralima nitida are soak in } \\
\text { water with Kafura or soak in hot drink without kafura }\end{array}$ & $\begin{array}{l}\text { Drink half stainless cup } \\
\text { two times daily if the } \\
\text { herbs are soaked in water } \\
\text { or one shot three times } \\
\text { daily if the herbs are soak } \\
\text { in hot drinks }\end{array}$ & $\begin{array}{l}\text { When it } \\
\text { becomes } \\
\text { tasteless }\end{array}$ \\
\hline 11 & $\begin{array}{l}\text { The roots of the Azadirachta indica with garlic (alubosa ayu) } \\
\text { and "kafura" are soaked in water for } 6 \text { hours. }\end{array}$ & $\begin{array}{l}\text { Drink half a cup every } \\
\text { morning. }\end{array}$ & $\begin{array}{l}\text { When it } \\
\text { becomes } \\
\text { tasteless }\end{array}$ \\
\hline 12 & $\begin{array}{l}\text { Squeeze fresh leaves of Vernonia amygdalina and fresh } \\
\text { leaves of red jatropha (Jatropha gossypifolia) with water. }\end{array}$ & Drink one glass cup & A day \\
\hline 13 & Squeeze the leaves of Triplochiton scleroxylon with water & Drink one glass cup & A day \\
\hline
\end{tabular}




\section{CONCLUSION}

The present study documented the traditional uses of medicinal plants used in the treatment of piles in the study area. It can be concluded from the findings of the studies that a total number of 25 plant species belonging to 19 families were used by the respondents in the treatments of piles in the study area. Fabaceae sub family of Caesalpinioidea, Mimisoideae and Palpilinoideae contributed the highest number of plant species used in the treatment of pile. Trees and shrubs were found to be the dominant growth form of medicinal plants while leaves and barks are found to be the most frequent used plant parts in the preparation of herbal medicine used in the treatment of piles. The study further revealed that the herb sellers, herbalists, hunters and aged are the custodian of traditional knowledge of medicinal plants used in the treatments of pile. Many of the medicinal plants used in the treatment of piles are rare and found in the wild, only very view are cultivated therefore, there is need for domestication, enduring and sustainable conservation efforts by the researchers, government and community to safeguard the loss of these medicinal plants. Also, there is need for standardization and precision on dosage of the herbal medicine. Further research should be carried out to confirm the efficacy of these medicinal plants and recipe used in the treatment of piles.

\section{CONSENT}

As per international standard, respondents' written consent has been collected and preserved by the authors. The respondents participated in the study out of their free will.

\section{ETHICAL APPROVAL}

As per international standard or university standard written ethical approval has been collected and preserved by the authors. The respondents provide information willingly to the study.

\section{COMPETING INTERESTS}

Authors have declared that no competing interests exist.

\section{REFERENCES}

1. Akinyemi B. Recent concept in plaque formation. J. Clin. Pathol. 2000;30:13-16.
2. Monier M. Abd El-Ghani. Traditional medicinal plants of Nigeria: An overview. Agriculture and Biology Journal of North America. 2016;7(5):220-247. ISSN Print: 2151-7517, ISSN Online: 2151-7525. ScienceHuß.

DOI: 10.5251/abjna.2016.7.5.220.247

Available:http://www.scihub.org/ABJNA

3. Diallo D, Hveem B, Mahmoud MA, Berge G, Paulsen BS, Maiga A. An ethnobotanical survey of herbal drugs of Gourma district, Mali. Pharm. Biol. 1999;37:80-91.

4. Lewis WH, Elvin-Lewis MP. Medical botany: Plants affecting human health. John Wiley and Sons, $2^{\text {nd }}$ Edition, New York. 2003;812.

5. Connie V, King R. An introduction to Ethnobotany. Shaman Pharmaceuticals Inc. 2003;628.

6. Hass PA, Fox TA, Hass GP. The pathogenesis of haemorrhoids. Dis. Colon Rectum. 1984;27:442-450.

7. Slezak FA, Thow GB. Combined ligationinjection treatment of haemorrhoids. Dis Colon Rectum. 1987;30:147-148.

8. Duke J. Foods as pharmaceuticals. In: Simon JE, Kestner A, Buchrie MA, (Eds). Herbs 89. Proceedings of the Fourth Herbs Growing and Marketing Conference, San Jose, CA. 1989;166-167.

9. Borokini TI, Ighere DA, Clement M, Ajiboye TO, Alowonle AA. Ethnobiological survey of traditional medicine practice for the treatment of piles and diabetes mellitus in Oyo State. Journal of Medicinal Plants Studies. 2013;1(5):30-40. ISSN: 23203862.

Available:www.plantsjournal.com

10. Gary J, Martins. Ethnobotany. A people and plants conservation manual. Chapman and Hall. U.K. 1995;268.

11. Treben M. Health through gods pharmacy: Advice and experiences with medicinal herbs. Ennsthaler 899, Austria. 1986;88.

12. Soladoye MO, Yakubu FA, Kola-Oladiji K, Alabi DA, Agbomeji YO. The collection, conservation and cultivation of local medicinal plants for natural medicine production. Paper Presented at the Seminar/Workshop and Exhibition of Natural Medicine Products. Organized by Nigeria Traditional Medical Association, ljebu-North in Collaboration with Faculty of Science, Olabisi Onabanjo University Agp-lwoye, Held 19-23 September; 2006. 
13. Soladoye MO, Adetayo MO, Chukwuma EC, Adetunji NA. Ethnobotanical survey of plants used in the treatment of haemorrhoids in South-Western Nigeria. Annals of Biological Research. 2010;1(4): 1-15.

14. Cox PA. The seven pillars of ethnomedical wisdom. Ethnobotany. 2005;17:24-34.

15. Trease A, Evans $H$. Pharmacognosy. Bailliere Tindall, London. 1989;832.

16. Wambebe C. Role of chemistry in the discovery of useful plants - derived drugs. The Delta Chemist. 1999;1(1):21-24.

17. Ekpendu T, Obande OE, Anayogo PU, Attah AD. Nigerian ethnomedicine and medicinal plant flora - the Benue experience. Part I. J. Pharm. Res. and Dev. 1998;3(1):37-46.

18. Balansard G, Timon DP. Anti-malarial activity of four plants used in traditional medicine in Mali. Phytother. Res. 2000;14: 45-47.

19. Singh NK, Singh DP. Ethnobotanical survey of Balrampur. Flora-fauna. 2001;7(2):59-66.

20. Wang Yu-Hua, Pei SJ, Xu JC. Sustainable management of medicinal plant resources in China: Literature review and implications. Resour. Sci. 2005;24(4):8188.

21. Kumar A, Tewari DD, Sharma R, Pandey VO. Practices of folk phyto veterinery in Devipatan division, Uttar Pradesh. Ind. J. Nactcon. 2005;17(1):153-161.

22. Pei S. Ethnobotany and development of new traditional Chinese medicine. Ethnobotany. 2005;17:35-40.

23. Yekinni OT, Oguntade MI. Training needs of women vegetable farmers in Akinyele Local Government Area of Oyo State, Nigeria. Tropical Agricultural Research \& Extension. 2014;17(1):38-44.

24. NPC. National Population Commission of Nigeria (web), National Bureau of Statistics (web); 2006.

25. Stella O. Odebode. Participation of elderly women in community welfare activities in Akinyele Local Government, Oyo State, Nigeria. Australian Journal of Adult Learning. 2009;49(3):596.

26. Gbile ZO, Soladoye MO. Vernacular names of Nigerian plants (Yoruba). $2^{\text {nd }} \mathrm{Ed}$, Forestry Research Institute of Nigeria, Ibadan. 2002;1-97.

27. Pronob G. Ethnobotanical study of certain medicinal plants for treatment of piles of Betbari area in Sivasagar District of
Assam, India. International Research Journal of Biological Sciences. 2016;5(4): 32-36.

Available:www.isca.in www.isca.me

28. Thiyam TS, Hanjabam MS, Anoubam RD, Hanjabam RS. Plants used in the treatment of piles by the scheduled caste community of Andro village in Imphal East District, Manipur (India). Journal of Plant Sciences. 2014;2(3):113-119.

29. Tilahun Tolossa Jima, Moa Megersa. Ethnobotanical study of medicinal plants used to treat human diseases in Berbere District, Bale Zone of Oromia Regional State, South East Ethiopia. Hindawi Evidence-Based Complementary and Alternative Medicine. 2018;16. Article ID: 8602945.

DOI: https://doi.org/10.1155/2018/8602945

30. Lulekal E, Kelbessa E, Bekele T, Yineger H. An ethnobotanical study of medicinal plants in Mana Angetu District, Southeastern Ethiopia. Journal of Ethnobiology and Ethnomedicine. 2008;4:10.

31. Hunde D, Asfaw Z, Kelbessa E. Use of traditional medicinal plants by people of 'Boosat' Sub district, Central Eastern Ethiopia. Ethiopian Journal of Health Sciences. 2006;16(2):141-155.

32. Regassa $R$, Bekele $T$, Megersa $M$. Ethnobotanical study of traditional medicinal plants used to treat human ailments by Halaba people, Southern Ethiopia. Journal of Medicinal Plants Studies. 2017;5(4):36-47.

33. Dike IP, Obembe OO. Towards conservation of Nigerian medicinal plants. Journal of Medicinal Plants Research. 2012;6(19):3517-3521. ISSN: 1996-0875.

DOI: $10.5897 / J M P R 10.612$

Available:http://www.academicjournals.org/

34. Lange D, Schippmann U. Trade survey of medicinal plants in Germany. Bundesamt für Naturschutz, Bonn. 1997;119.

35. Srivastava JL, Vietmeyer N. Medicinal plants. An expanding role in development. The World Bank, Washington DC (World Bank Technical Paper 320). 1996;21.

36. Ariyo OC. Socio-economic and botanic analysis of West bank forest and Block $A$ Forest of IITA, Ibadan, Oyo State, Nigeria. Unpublished Ph.D. Thesis. University of Agriculture, Abeokuta, Ogun State, Nigeria. 2018;302.

37. Beltrán-Rodríguez L, Ortiz-Sánchez A, Mariano NA, Maldonado-Almanza B, 
Reyes García V. Factors affecting ethnobotanical knowledge in a mestizo community of the Sierra de Huautla Biosphere Reserve Mexico. Journal of Ethnobiology and Ethnomedicine. 2014;10: 14.

38. Katewa SS, Chaudhary BL, Jain, Anita. Folk herbal medicines from tribal area of Rajasthan, India. Journal of Ethnopharmacology. 2004;92:41-46.

39. Alemayehu G, Asfaw Z, Kelbessa E. Ethnobotanical study of medicinal plants used by local communities of MinjarShenkora District, North Shewa zone of Amhara Region, Ethiopia. Journal of Medicinal Plants Studies. 2015;3(6):1-11.

40. Abera B. Medicinal plants used in traditional medicine in Jimma Zone, Oromia Regional State Southwest Ethiopia. Ethiopian Journal Health Sciences. 2003;13:85-94.

41. Bekalo TH, Woodmatas SD, Woldemariam ZA. An ethnobotanical study of medicinal plants used by local people in the lowlands of Konta Special Woreda, Southern Nations, Nationalities and Peoples Regional State, Ethiopia. Journal of Ethnobiology and Ethnomedicine. 2009;5. Article 26.

42. Kitata G, Abdeta D, Amante M. Ethnoknowledge of plants used in veterinary practices in Midakegn district, West Showa of Oromia region, Ethiopia. Journal of Medicinal Plants Studies. 2017;5(5):282-288.

43. Lulekal E, Asfaw Z, Kelbessa E, Van Damme P. Ethnomedicinal study of plants used for human ailments in Ankober District, North Shewa Zone, Amhara Region, Ethiopia. Journal of Ethnobiology and Ethnomedicine. 2013;9. Article 63.

44. Mesfin F, Demissew S, Teklehaymanot T. An ethnobotanical study of medicinal plants in Wonago Woreda, SNNPR, Ethiopia. Journal of Ethnobiology and Ethnomedicine. 2009;5. Article 28.

45. Wassihun B, Asfaw Z, Demissew S. Ethnobotanical study of useful plants in Daniio Gade (Home-Gardens) in Southern Ethiopia. Ethiopian J. Biolog. Sci. 2003;2(2):119-141.

46. Hunde D, Asfaw Z, Kelbessa E. Use and management of ethno veterinary medicinal plants by indigenous people in 'Boosat', Wolenchiti area. Ethiopian J. Biolog. Sci. 2004;3(2):113-132.

47. Oladunmoye MK, Kehinde FY. Ethnobotanical survey of medicinal plants used in treating viral infections among Yoruba tribe of South Western Nigeria. African Journal of Microbiology Research. 2011;5(19):2991-3004. ISSN: 1996-0808. DOI: 10.5897/AJMR10.004

Available:http://www.academicjournals.org/ ajmr

48. Sofowora A. Medicinal plants and traditional medicine in Africa. New York: John Wiley and Sons Ltd; 1982.

49. Yirga G. Ethnobotanical study of medicinal plants in and around Alamata, Southern Tigray, Northern Ethiopia. Current Research Journal of Biological Sciences. 2010;2:338-344.

(c) 2020 Ariyo et al.; This is an Open Access article distributed under the terms of the Creative Commons Attribution License (http://creativecommons.org/licenses/by/4.0), which permits unrestricted use, distribution, and reproduction in any medium, provided the original work is properly cited. http://www.sdiarticle4.com/review-history/57648 